\title{
NOTES ON THE BIOLOGY AND ECOLOGY OF LABIDOSTOMMA (ACARI PROSTIGMATA LABIDOSTOMMIDAE) IN POLAND
}

\author{
(*) Department of General Zoology, Faculty of Biology, Adam Mickiewicz University, ul Umultowska 89;61-614 \\ Poznań, Poland; e-mail: agan@amu.edu.pl \\ (**) Natural History Collections, Faculty of Biology, Adam Mickiewicz University, ul Umultowska 89; 61-614 Poznań, \\ Poland \\ ${ }^{* * *)}$ Electron and Confocal Microscope Laboratory/Department of Animal Physiology and Development, Faculty of \\ Biology, Adam Mickiewicz University, ul Umultowska 89; 61-614 Poznań, Poland \\ $\left(^{\circ}\right)$ Corresponding author: agan@amu.edu.pl
}

Błoszyk J., Adamski Z., Napierała A. - Notes on the biology and ecology of Labidostomma (Acari Prostigmata Labidostommidae) in Poland.

The current article is a brief summary of results obtained from long-term observations (for over 67 years) of Labidostommatidae mites in Poland. The study is based on 21,470 samples collected in different environments and different locations, and each of them had a different protection status. The analysis focuses on the frequency of occurrence and habitat preferences of Labidostomma luteum Kramer, 1879, Labidostomma denticulatum (Schrank, 1776) and Labidostomma cornutum (G. Canestrini \& Fanzago, 1878) in Poland. The results of the analysis show that $L$. luteum was the most frequent species found in the analyzed material, whereas specimens of L. cornutum were very rare. Moreover, the long-term research conducted in Poland since 1950 has allowed to analyze changes in the average abundance of the examined species in this area. The results of the analysis has revealed a decrease in the abundance of L. luteum, which is evident especially after 1990. Finally, the comparison of the abundance of Labidostomma in legally protected areas and those without any legal protection shows that the mites definitely prefer areas with a low anthropogenic pressure.

KeY WoRDS: Labidostomma, habitat preferences, spatial distribution, protected areas, changes in abundance.

\section{INTRODUCTION}

There are three species belonging to the family Labidostommatidae which occur in Poland, i.e. Labidostomma luteum Kramer, 1879, Labidostomma denticulatum (Schrank, 1776) and Labidostomma cornutum (G. Canestrini \& Fanzago, 1878). In 1980 Błoszyk published an article in which he showed for the first time that the geographical range and ecological niches of species from the cohort Labidostommatina can be different. Later studies has also confirmed that these mites are most common in natural biotopes, and their populations disappear due to increasing anthropogenic pressure (BŁOSZYK et al., 1988, 2007; BŁOSZYK and CZARNOTA, 1998a, 1998b).

However, most of the studies mentioned above are based on small samples number, e.g. 718 samples were used in BŁosZYK (1980). This study compares the habitat requirements of the three Labidostomma species occurring in Poland based on new data and over 7,000 samples. To confirm that the mites prefer habitats with a low anthropogenic pressure (BŁosZYK et al., 1988, 2007; BŁosZYK and CZARNOTA, 1998a, 1998b), we compared the occurrence of the three Labidostomma species in legally protected areas, such as national parks and reserves, as well as areas with no legal protection. Furthermore, the long-term research has also allowed analyzing the changes in the abundance of Labidostomma species since the end of the 50's until 2017. This study, beside the work by BŁoszYK et al. (2017), who discuss the vertical and geographical distribution, as well as the post-glacial migration of mites from the genus Labidostomma in Europe, is a summary of the current knowledge in the biology, ecology, and distribution of these mites in Poland.

\section{MATERIAL AND METHODS}

The study presents an analysis of samples which were collected in Poland between 1950 and 2017 by different researchers. The total analyzed sample material contained 21,470 soil samples and samples from unstable microhabitats collected from protected (national parks and nature reserves) and unprotected areas (7,528 qualitative and quantitative 13,942 samples). On the basis of these samples a map showing the distribution of Labidostomma in Poland has been drawn (Fig. I). The material analyzed in this study contained only qualitative samples, which contained all necessary information about the environment and legal protection status of the area in which they were collected.

Sampling was done by sieving soil and forest litter, whereas the samples which were not sieved had been collected in open habitats, such as meadows, dead wood, and tree holes. The samples from dead wood were collected with plastic container and had a volume from 0.5-0.8 1. All the samples were extracted with Tullgren funnels for 4-6 days (depending on the level of moisture) just after the material collection. The extracted mites were preserved in $75 \%$ ethyl alcohol. The specimens found in the samples were identified with an Olympus SZ30 stereomicroscope. Due to the fact that Labidostomma luteum, L. denticulatum, and $L$. cornutum had been described in earlier studies, and 


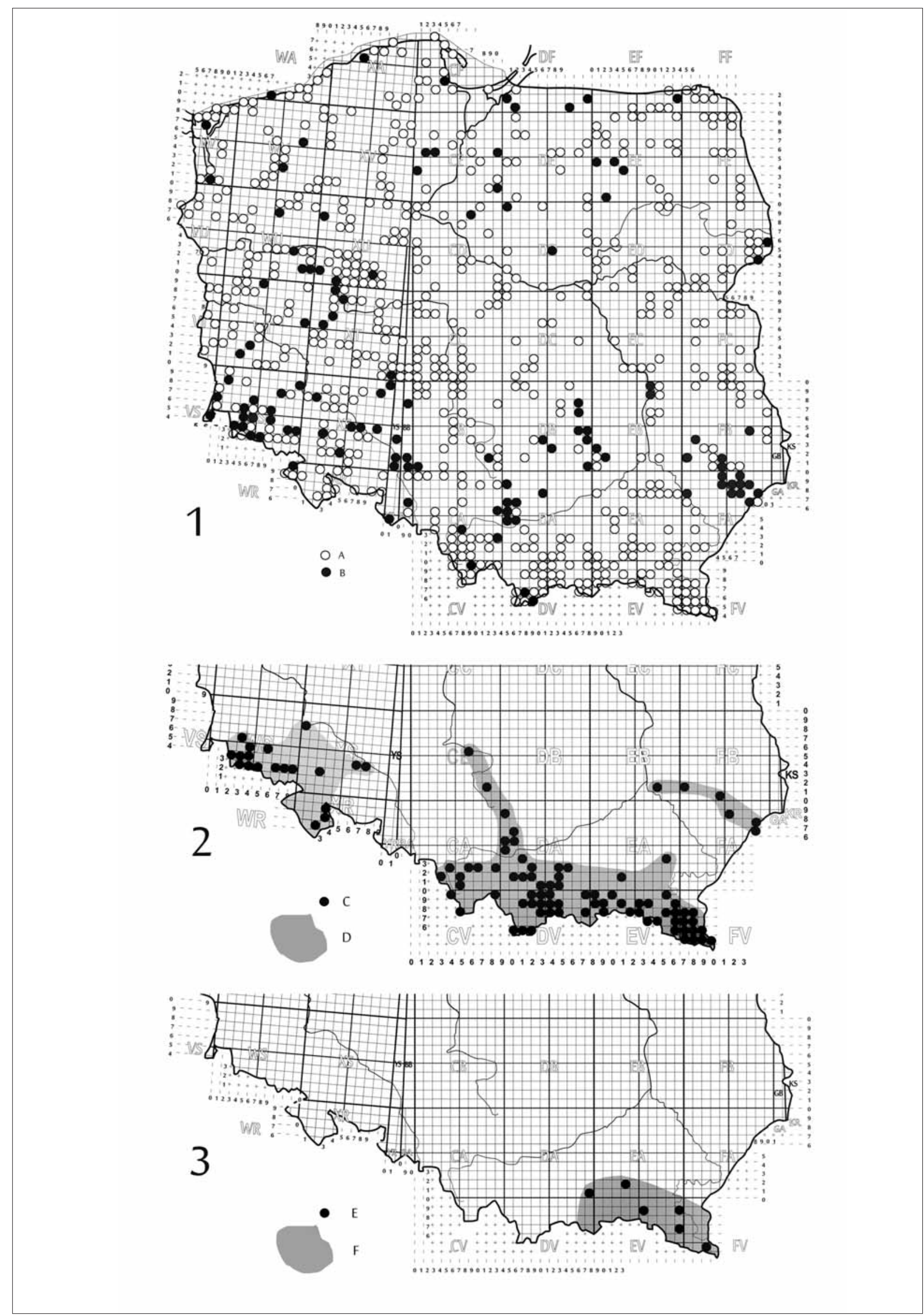

Fig. I - Distribution of Labidostomma species in Poland: 1: A - examined plots with no Labidostomma, B - plots with Labidostomma luteum; 2: C - plots with Labidostomma denticulatum, D - presumable area of occurrence of the species; 3 : E - plots with Labidostomma cornutum, F - presumable area of occurrence of the species. 
the descriptions provided by ŠTORKAN (1939) and GRANDJEAN (1942a, 1942b) seem to be very thorough, this study primarily focuses on the ecology and distribution of the species in question. The mites were classified on the basis of the original descriptions (ŠTORKAN, 1939; GRANDJEAn 1942a, 1942b, Pfliegler \& Bertand, 2011). The examined specimens are stored in the Invertebrate Database, which is a part of the Natural History Collection, housed in the Faculty of Biology at Adam Mickiewicz University in Poznań.

The map showing the distribution of the mites in Poland (Fig. I) was drawn on the basis of the UTM grid $(10 \times 10$ $\mathrm{km})$. An analysis of long-term changes in the average number of Labidostomma species was carried out between 1950 and 2017. The only exception was the first research period (1950-1969) which covers 20 years due to the a low number of samples collected at the first stage of the project. In addition, we believe that anthropogenic changes of the environment were fairly slow at that time. In order to estimate the statistical significance of differences between average abundance of $L$. luteum and $L$. denticulatum in protected and unprotected areas, Student's T-test was used.

\section{RESULTS}

FREQUENCY OF THE THREE LABIDOSTOMMA SPECIES IN POLAND

The three species were found in 721 samples $(9.58 \%$ frequency) out of all 7,528 qualitative samples collected in the whole area of Poland. The samples contained 3,160 specimens of mites from this group $[L$. luteum $(1,631), L$. denticulatum $(1,506)$ and $L$. cornutum $(23)$ specimens]. $L$. luteum occurred in $42.3 \%$ of the positive samples, $L$. denticulatum in $56.2 \%$, and L. cornutum only in $1.5 \%$ of the samples. The specimens of the latter species were apparently rare - the average number of specimens in each of these positive samples was merely 4 . The highest number of specimens in one sample was recorded for L. luteum, 57 specimens, in the case of $L$. denticulatum, 24 specimens, whereas $L$. cornutum was represented only by 6 specimens.

Changes of ABUNDANCE AND FREQUENCY OF THREE

\section{LABIDOSTOMMA SPECIES IN POLAND}

The average number of the Labidostomma species in the positive samples in the local populations of $L$. denticulatum and $L$. cornutum in the examined areas is not decreasing over time, and their abundance is rather stable (Table 1). The situation is different in the case of L. luteum, the abundance of which decreased considerably after 1990.

The frequency of the two most common species L. luteum and $L$. denticulatum, was quite stable in the first three research periods (Table 2). A considerable decrease of this parameter has been observed after 1990 in the case of $L$. luteum. On the other hand, the data for L. denticulatum show that this species was the most frequent between 1990 and 1999 (Table 2).

\section{HABITAT PREFERENCES OF THE THREE SPECIES}

The habitat and microhabitat preferences in the three species from genus Labidostomma were established on the basis of the qualitative samples. The habitats, in which the analyzed specimens were collected, can be classified into three major groups: (1) open, non-wooded areas, (2) woods and shrubs and (3) unstable microhabitats (merocenoses). A detailed list of the habitats with statistical data is given below in Table 3.

In Poland, species of Labidostomma are the most common in woods and shrubs (Table 3). The three species were found in hornbeam forests, mixed deciduous forests, beechwoods in the mountains, mixed forests (with spruce), and brushwoods. Only one species - L. luteum, inhabits beechwoods of lowlands, pine forests, spruce forests in lowlands, and larch stands. On the other hand, L. denticulatum can be found only in areas with dwarf pines. The three species are

Table 1 - Changes in the average number of specimens (X) in positive samples observed in Poland from 1950 to 2017: Ps - positive samples, $\mathrm{N}$ - number of specimens, Max - maximum number of specimens in one sample.

\begin{tabular}{|c|c|c|c|c|c|c|c|c|c|c|c|c|c|}
\hline \multirow{2}{*}{ Study period } & \multirow{2}{*}{$\begin{array}{c}\text { Number } \\
\text { of soil } \\
\text { samples }\end{array}$} & \multicolumn{4}{|c|}{ L. luteum } & \multicolumn{4}{|c|}{ L. denticulatum } & \multicolumn{4}{|c|}{ L. cornutum } \\
\hline & & Ps & $\mathbf{N}$ & $\mathbf{X}$ & Max & Ps & $\mathbf{N}$ & $\mathbf{X}$ & Max & Ps & $\mathbf{N}$ & $\mathbf{X}$ & Max \\
\hline 1950-1969 & 286 & 11 & 30 & $2.7 \pm 2.8 \mathrm{SD}$ & 10 & 25 & 118 & $4.7 \pm 4.7 \mathrm{SD}$ & 17 & 4 & 7 & $1.7 \pm 0.9 \mathrm{SD}$ & 3 \\
\hline $1970-1979$ & 1,295 & 110 & 612 & $5.6 \pm 6.9 \mathrm{SD}$ & 45 & 115 & 405 & $3.5 \pm 3.8 \mathrm{SD}$ & 24 & 3 & 6 & $2.0 \pm 1.7 \mathrm{SD}$ & 4 \\
\hline 1980-1989 & 1,788 & 85 & 452 & $5.3 \pm 6.9 \mathrm{SD}$ & 46 & 47 & 115 & $2.4 \pm 1.9 \mathrm{SD}$ & 12 & - & - & - & - \\
\hline 1990-1999 & 1,294 & 23 & 98 & $4.3 \pm 4.2 \mathrm{SD}$ & 18 & 197 & 834 & $4.2 \pm 3.7 \mathrm{SD}$ & 24 & - & - & - & - \\
\hline $2000-2010$ & 2,074 & 41 & 245 & $6.0 \pm 9.9 \mathrm{SD}$ & 57 & 2 & 2 & $1 \pm$ & 1 & - & - & - & - \\
\hline $2011-2017$ & 791 & 35 & 194 & $5.5 \pm 5.9 \mathrm{SD}$ & 22 & 19 & 32 & $1.7 \pm 1.1 \mathrm{SD}$ & 5 & 4 & 10 & $2.5 \pm 2.4 \mathrm{SD}$ & 6 \\
\hline
\end{tabular}

Table 2 - Frequency of Labidostomma species in Poland between 1950 and 2017.

\begin{tabular}{|c|c|c|c|}
\hline \hline Study period & L. luteum & L. denticulatum & L. cornutum \\
\hline $1950-1969$ & 3.85 & 8.74 & 1.40 \\
\hline $1970-1979$ & 8.49 & 8.88 & 0.23 \\
\hline $1980-1989$ & 4.75 & 2.63 & - \\
\hline $1990-1999$ & 1.78 & 15.22 & - \\
\hline $2000-2010$ & 1.98 & 0.10 & - \\
\hline $2011-2017$ & 4.42 & 2.40 & 0.51 \\
\hline
\end{tabular}

rare in open habitats. L. luteum clearly prefers xerophilous grasses, but both species are apparently frequent in rock grasses on limestones. L. luteum and L. denticulatum, were the most frequent in unstable microhabitats, like rotten trunks and tree holes. L. cornutum occurred in mixed forests (with spruce trees), brushwood, beech-woods in the mountains, and in hornbeam forests.

\section{OCCURRENCE OF LABIDOSTOMMA IN PROTECTED} AND UNPROTECTED AREAS

In this study, 5,427 samples that were collected in habitats preferred by the mites from this group have been 
Table 3 - Habitat preference of two species of Labidostomma in Poland: N - number of qualitative samples; F - frequency (\%); Ns - number of specimens; $x$ - mean of specimens/per sample, SD - standard deviation.

\begin{tabular}{|c|c|c|c|c|c|}
\hline Habitat & Species & $\mathbf{N}$ & $\mathbf{F}$ & Ns & $\mathbf{X} \pm$ SD \\
\hline \multicolumn{6}{|l|}{ Open habitat } \\
\hline Xerophilous grasses & L. luteum & 78 & 7.69 & 65 & $10.8 \pm 17.7$ \\
\hline Sandhills & & 25 & & & \\
\hline Rock grasses (non-calcareous) & $\begin{array}{l}\text { L. denticulatum } \\
\text { L. luteum }\end{array}$ & 168 & $\begin{array}{l}2.98 \\
1.19\end{array}$ & $\begin{array}{l}8 \\
6\end{array}$ & $\begin{array}{l}1.6 \pm 0.9 \\
3.0 \pm 1.4\end{array}$ \\
\hline Rock grasses on limestone & $\begin{array}{l}\text { L. denticulatum } \\
\text { L. luteum }\end{array}$ & 103 & $\begin{array}{l}8.74 \\
9.71 \\
\end{array}$ & $\begin{array}{l}25 \\
40\end{array}$ & $\begin{array}{l}2.8 \pm 2.0 \\
4.0 \pm 2.8 \\
\end{array}$ \\
\hline Meadows & L. luteum & 578 & 0.17 & 1 & 1.0 \\
\hline Peat-bogs & $\begin{array}{l}\text { L. denticulatum } \\
\text { L. luteum }\end{array}$ & 82 & $\begin{array}{l}1.22 \\
4.88\end{array}$ & $\begin{array}{r}1 \\
11 \\
\end{array}$ & $2.7 \pm 2.1$ \\
\hline Sedgelands & L. luteum & 25 & 4.00 & 1 & 1.0 \\
\hline \multicolumn{6}{|l|}{ Forest and shrubs } \\
\hline Alder forest & $\begin{array}{l}\text { L. denticulatum } \\
\text { L. luteum }\end{array}$ & 142 & $\begin{array}{l}0.70 \\
2.82 \\
\end{array}$ & $\begin{array}{r}3 \\
70 \\
\end{array}$ & $\begin{array}{c}3.0 \\
17.5 \pm 26.6 \\
\end{array}$ \\
\hline Marshy forest & $\begin{array}{l}\text { L. denticulatum } \\
\text { L. luteum }\end{array}$ & 213 & $\begin{array}{l}0.47 \\
1.41\end{array}$ & $\begin{array}{r}3 \\
16\end{array}$ & $\begin{array}{c}3.0 \\
5.3 \pm 3.2\end{array}$ \\
\hline Oak-hornbeam forest & $\begin{array}{l}\text { L. cornutum } \\
\text { L. denticulatum } \\
\text { L. luteum }\end{array}$ & 497 & $\begin{array}{r}0.60 \\
3.82 \\
10.66 \\
\end{array}$ & $\begin{array}{r}9 \\
88 \\
304 \\
\end{array}$ & $\begin{array}{l}3.1 \pm 1.0 \\
4.6 \pm 4.3 \\
5.7 \pm 7.7\end{array}$ \\
\hline Mixed deciduous forest & $\begin{array}{l}\text { L. cornutum } \\
\text { L. denticulatum } \\
\text { L. luteum }\end{array}$ & 265 & $\begin{array}{l}0.21 \\
4.64 \\
5.70\end{array}$ & $\begin{array}{r}1 \\
68 \\
222 \\
\end{array}$ & $\begin{array}{c}1.0 \\
3.1 \pm 2.7 \\
7.4 \pm 6.6\end{array}$ \\
\hline Beech-wood in lowlands & L. luteum & 95 & 14.74 & 55 & $3.9 \pm 5.7$ \\
\hline Beech-wood in the mountains & $\begin{array}{l}\text { L. cornutum } \\
\text { L. denticulatum } \\
\text { L. luteum }\end{array}$ & 499 & $\begin{array}{r}0.20 \\
36.67 \\
5.21\end{array}$ & $\begin{array}{r}1 \\
770 \\
84\end{array}$ & $\begin{array}{c}1.0 \\
4.2 \pm 3.6 \\
3.2 \pm 4.2\end{array}$ \\
\hline Oak-wood & $\begin{array}{l}\text { L. denticulatum } \\
\text { L. luteum }\end{array}$ & 58 & $\begin{array}{r}1.72 \\
12.07 \\
\end{array}$ & $\begin{array}{r}1 \\
54\end{array}$ & $\begin{array}{c}1.0 \\
7.7 \pm 7.0\end{array}$ \\
\hline Pine artyfical tree stands and pine forest & $\begin{array}{l}\text { L. denticulatum } \\
\text { L. luteum }\end{array}$ & 585 & $\begin{array}{l}0.34 \\
3.76\end{array}$ & $\begin{array}{r}2 \\
87\end{array}$ & $\begin{array}{c}1.0 \\
4.0 \pm 3.7\end{array}$ \\
\hline Spruce forest in the mountains & $\begin{array}{l}\text { L. denticulatum } \\
\text { L. luteum }\end{array}$ & 309 & $\begin{array}{l}8.41 \\
0.97\end{array}$ & $\begin{array}{r}87 \\
9 \\
\end{array}$ & $\begin{array}{l}3.0 \pm 3.7 \\
3.0 \pm 2.0\end{array}$ \\
\hline Spruce forest in lowland & L. luteum & 49 & 6.12 & 10 & $3.3 \pm 1.2$ \\
\hline Fir forest & $\begin{array}{l}\text { L. denticulatum } \\
\text { L. luteum }\end{array}$ & 126 & $\begin{array}{r}37.30 \\
2.38 \\
\end{array}$ & $\begin{array}{r}143 \\
7 \\
\end{array}$ & $\begin{array}{l}3.0 \pm 2.9 \\
2.3 \pm 1.2\end{array}$ \\
\hline Larch stand & L. luteum & 30 & 13.33 & 20 & $5.0 \pm 2.2$ \\
\hline Yew-tree stand & L. luteum & 90 & 2.22 & 2 & 1.0 \\
\hline Fir-beech forest & $\begin{array}{l}\text { L. denticulatum } \\
\text { L. luteum }\end{array}$ & 66 & $\begin{array}{l}36.36 \\
12.12\end{array}$ & $\begin{array}{l}89 \\
19\end{array}$ & $\begin{array}{l}3.7 \pm 3.1 \\
2.4 \pm 2.4\end{array}$ \\
\hline Mixed forest (with pine) & $\begin{array}{l}\text { L. denticulatum } \\
\text { L. luteum }\end{array}$ & 232 & $\begin{array}{l}0.43 \\
6.47 \\
\end{array}$ & $\begin{array}{r}2 \\
122 \\
\end{array}$ & $\begin{array}{l}3.7 \pm 3.1 \\
8.1 \pm 8.8\end{array}$ \\
\hline Mixed forest (with spruce) & $\begin{array}{l}\text { L. cornutum } \\
\text { L. denticulatum } \\
\text { L. luteum }\end{array}$ & 90 & $\begin{array}{r}1.11 \\
13.33 \\
8.89 \\
\end{array}$ & $\begin{array}{r}1 \\
76 \\
46 \\
\end{array}$ & $\begin{array}{c}1.0 \\
6.3 \pm 7.3 \\
6.0 \pm 6.5 \\
\end{array}$ \\
\hline Dwarf pine & L. denticulatum & 55 & 3.64 & 7 & $3.5 \pm 2.1$ \\
\hline Bushwood & $\begin{array}{l}\text { L. cornutum } \\
\text { L. denticulatum } \\
\text { L. luteum }\end{array}$ & 120 & $\begin{array}{l}0.83 \\
7.50 \\
4.17 \\
\end{array}$ & $\begin{array}{r}1 \\
26 \\
36 \\
\end{array}$ & $\begin{array}{c}1.0 \\
2.9 \pm 3.3 \\
7.2 \pm 5.6\end{array}$ \\
\hline Parks & $\begin{array}{l}\text { L. denticulatum } \\
\text { L. luteum }\end{array}$ & 171 & $\begin{array}{l}0.58 \\
5.26 \\
\end{array}$ & $\begin{array}{r}2 \\
48 \\
\end{array}$ & $\begin{array}{c}2.0 \\
5.3 \pm 4.6\end{array}$ \\
\hline \multicolumn{6}{|l|}{ Merocenoses } \\
\hline Ant-hills & & 42 & & & \\
\hline Nests of small mammals & L. luteum & 233 & 0.45 & 1 & 1.0 \\
\hline Nests of birds & & 821 & & & \\
\hline Rotten trunks & $\begin{array}{l}\text { L. denticulatum } \\
\text { L. luteum }\end{array}$ & 1,224 & $\begin{array}{l}1.55 \\
3.19\end{array}$ & $\begin{array}{r}57 \\
150\end{array}$ & $\begin{array}{l}3.0 \pm 3.9 \\
3.8 \pm 4.7\end{array}$ \\
\hline Tree hollows & $\begin{array}{l}\text { L. denticulatum } \\
\text { L. luteum }\end{array}$ & 193 & $\begin{array}{l}1.73 \\
1.73\end{array}$ & $\begin{array}{r}9 \\
39\end{array}$ & $\begin{array}{c}3.0 \pm 2.6 \\
13.0 \pm 12.1\end{array}$ \\
\hline Total & & 7,264 & & 3,005 & \\
\hline
\end{tabular}

*Reported on 30.11 .2017 
analyzed; out of which 1,809 samples $(33.3 \%)$ were collected in nature reserves and national parks. The other 3,618 samples were collected in areas with no legal protection status. Despite the higher number of samples collected in unprotected areas, over half of the found specimens $(55.7 \%)$ come from the samples collected in reserves and national parks (Table 4). Also the frequency of the three species was higher in the samples collected in legally protected areas (Fig. II).

The data show that Labidostomma species are more abundant in protected areas. The average number of the two most common species in a positive sample (i.e. a sample containing a given species) was higher in protected areas (Fig. III). However, this difference is statistically significant only in the case of $L$. denticulatum [t 6,02 df $1098 \mathrm{p}=0,00$ $\mathrm{N} 550]$, whereas the differences in the average abundance of L. luteum in protected and unprotected areas is not statistically significant [t 1,83 df $1098 \mathrm{p}=0,07 \mathrm{~N} 550]$.

Table 4 - Number of specimens (N) and positive samples (PS) for Labidostomma species in protected and unprotected areas; NSp total number of specimens, Nsa - total number of samples.

\begin{tabular}{|l|r|r|r|r|r|}
\hline \hline \multirow{2}{*}{ Species } & \multicolumn{2}{|c|}{ Protected } & \multicolumn{2}{|c|}{ Unprotected } & \\
\cline { 2 - 6 } & \multicolumn{1}{|c|}{ N } & \multicolumn{1}{c|}{ PS } & \multicolumn{1}{c|}{ N } & \multicolumn{1}{c|}{ PS } & NSp \\
\hline L. luteum & 517 & 90 & 504 & 108 & 1,021 \\
\hline L. denticulatum & 790 & 206 & 523 & 351 & 1,313 \\
\hline L. cornutum & 1 & 1 & 12 & 6 & 13 \\
\hline Nsa & 1,308 & 1,809 & 1,039 & 3,618 & 5,427 \\
\hline
\end{tabular}

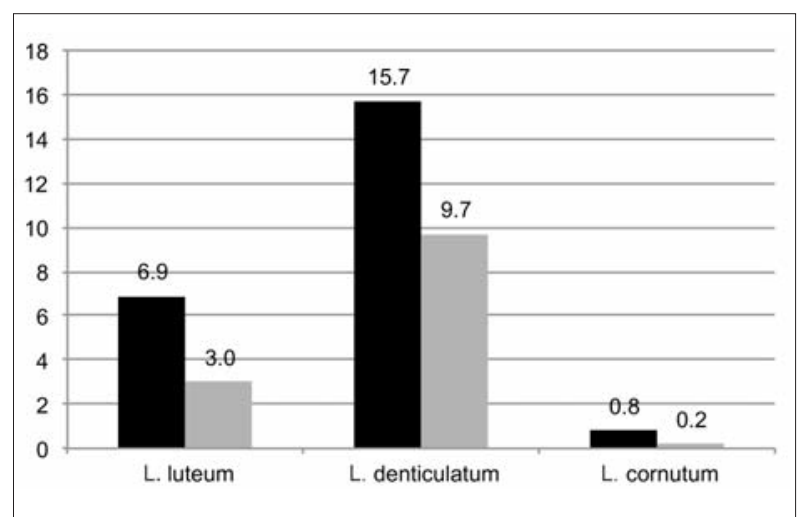

Fig. II - Frequency (\%) of Labidostomma species in samples from protected (black) and unprotected (gray) areas.

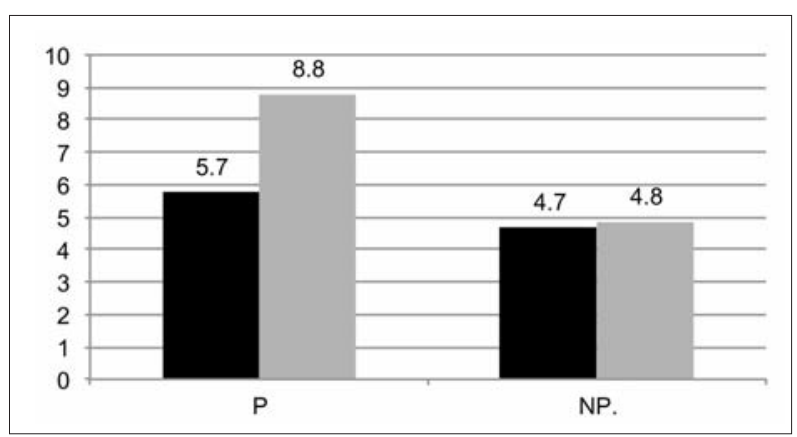

Fig. III - Average number of specimens per positive sample in protected $(\mathrm{P})$ and not protected areas (NP). Black - L. luteum, gray - L. denticulatum.

\section{DISCUSSION}

Despite the fact that it has been 38 years since BŁOSZYK (1980) published his first study on mites from the cohort Labidostommatina in Poland, which was based on material containing a relatively low number of samples (718 samples), the current knowledge of the distribution and habitat preferences of these species has not changed much since that time. Our study is therefore a significant contribution to the research into Labidostomma mites in Poland, especially the data on the habitat preferences and changes in the abundance of the mites between the 50's and 2017. The analysis presented in this study has been carried out on a large number of qualitative samples, and in most cases the results corroborate the earlier observations on the habitat preferences of the discussed species. Similarly to the earlier studies, our results also show that the three Labidostomma species occurred most frequently in oak-hornbeam forests, beechwood forests, both in lowlands and highlands, in mixed forests, as well as in mixed forests with spruce, and in brushwoods (Table 2). Besides this, L. luteum occurred also in larch stands and in oak-woods, which has not been recorded in the earlier study by BŁosZYK (1980).

The data presented in this study also provide new valuable information for example, the occurrence of Labidostomma species in legally protected areas and those with no legal protection status. The obtained results have confirmed that the three species definitely prefer areas with low anthropogenic pressure (BŁOSZYK, 1980). Despite the fact that the number of samples collected in protected areas was considerably lower, the frequency of the three species was much higher than in those collected in areas that were not protected. Also the abundance of L. luteum and L. denticulatum, which are the two most common Labidostomma species in Poland, was higher. This is especially noticeable for L. denticulatum. Moreover, the frequency of this species was also higher in legally protected areas. A similar dependency has been also observed in the case of mites from the suborder Uropodina (NAPIERAŁA, 2008, 2009). The research conducted in Wielkopolska (Greater Poland) shows that $80 \%$ of all species of Uropodina found so far in Wielkopolska occurred mainly in legally protected areas (nature reserves and the Wielkopolski National Park), though protected areas constitute only $2 \%$ of the whole area of the region.

Another important problem that has not been discussed previously is the changes in the abundance and frequency over time of the three species of Labidostomma. The frequency of particular species found in the samples collected in the consecutive time periods fluctuated depending on the number of samples and place where the samples were collected. This probably stems from the fact that distribution of these mites is geographically restricted to a given area and is different for each species (BŁOSZYK, 1980; BŁoszYK et al., 2017). The high frequency of $L$. denticulatum in the period 1990-1999 was probably caused by the great intensity of the research carried out at that time in the Gorce Mountains, where most of the analyzed samples were collected (Table 2). The changes of the average number of specimens in the positive samples show that the local populations of $L$. denticulatum and $L$. cornutum in the examined areas are not diminishing and their abundance is fairly stable (Table 1). The situation is different in the case of $L$. luteum, the abundance of which considerably decreased after 1990 . This in turn probably stems from the fact that in this period the area of Wielkopolska (Greater Poland), where much of the 
analysed material was collected, suffered from a low rainfall and severe cold winters with no snow cover. Further research should provide more data which will show whether this situation has become a definite trend.

A similar decrease of abundance has also been observed in the case of Uropodina in two nature reserves, i.e. in Jakubowo and Las Grądowy (Greater Poland), which have been under survey for 36 years (NAPIERAta et al., 2014). During this very long period of time extensive research was conducted in these reserves, and also abundance of a small population of L. luteum has been monitored in Jakubowo reserve since the 80 's. The observations show that the abundance of this species considerably decreased after 1990. The decrease was caused probably not only by the climate conditions, but also by the extensive successive changes in the vegetation of the observed area. It is also noteworthy that during this period, one species of mites from the suborder Uropodina, i.e. Trachytes lamda (BERLESE, 1903) has became extinct in this reserve. This is a rare mite species, which is very sensitive to unfavorable environmental changes (BŁOSZYK, 1999). The extinction of this rare Uropodina and a decrease in the abundance of $L$. luteum in this area imply that there have been some deteriorating changes in the environment conditions in the area of the reserve. This also supports the hypothesis that Labidostomma species prefer areas with a low anthropogenic pressure, and therefore, these species can be good bioindicators of natural soil health.

\section{REFERENCES}

BŁoszyK J., 1980 - Badania nad rodzina Nicoletiellidae (Acari, Prostigmata) w Polsce. - Pr. Kom. Biol. PTPN, 54: 53-85.

BŁosZYK J., 1999 - Geograficzne i ekologiczne zróżnicowanie zgrupowań roztoczy z kohorty Uropodina (Acari: Mesostigmata) w Polsce. 1. Uropodina lasów gradowych (Carpinion betuli). Kontekst, Poznań, 245 pp. [Summary in english]

BŁoszyK J., Czarnota P., 1998a - Roztocze glebowe z kohorty Uropodina i Labidostommatina jako indykatory zasadności renaturalizacji lasu w Gorczańskim Parku Narodowym. - Przegl. Przyr., 9: 119-126.

BŁoszyk J., Czarnota P., 1998b - Wplyw wybranych czynników na liczebność i rozmieszczenie Nicoletiella denticulatum (Schrank, 1776) (Acari: Actinedida,
Labidostomatina) w Gorczańskim Parku Narodowym, w porównaniu ze zdegradowanymi środowiskami Karkonoszy i Gór Izerskich. - Parki Nar. Rez. Przyr., 17: 31-49.

BŁoszyk J., Jackiewicz M., Olszanowski Z., 1988 Materiaty do znajomości akarofauny Roztocza. I. Labidostommidae (Acari: Actinedida). - Przegl. Zool., 32: 387-392.

BŁoszYK J., Konwerski Sz., NAPIERAŁA A., GAWroŃSKa K., GoŁdyn B., 2007 - Spatial distribution and habitat preferences of Labidostomma denticulatum (Acari: Prostigmata) in Gorce National Park (Southern Poland). Biol. Lett., 44:1-10.

BŁoszyK J., KsiążKIEWICZ-PARUlska Z., AdAMSKi Z., NAPIERAŁA A., 2017 - Influence of Pleistocene glaciation on the distribution of three species of Labidostomma in Europe (Acari: Labidostommatidae). - Syst. Appl. Acarol., 22: 841-857.

GrandjeAn F., 1942a - Observations sur les Labidostomidae (1.ser.). - Bull. du Mus. Nat. Hist. Nat., 2 ser., 14: 185-192.

GrandjeAn F., 1942b - Observations sur les Labidostomatide (1.ser.). - Bull. du Mus. Nat. Hist. Nat., 2 ser., 14: 319-326.

NAPIERAŁA A., 2008 - Struktura zgrupowań $i$ rozkład przestrzenny Uropodina (Acari: Mesostigmata) $w$ wybranych kompleksach leśnych Wielkopolski $[\mathrm{PhD}$ Dissertation]. Adam Mickiewicz University, Poznań, $188 \mathrm{pp}$

NAPieraŁa A., BŁoszyK J., Bruin J., 2009 - Communities of uropodine mites (Acari: Mesostigmata) in selected oakhornbeam forests of the Wielkopolska region (Poland). Exp. Appl. Acarol., 49: 291-303.

NAPIERAŁA A., LABIJAK B., SKwIERCZyŃSKI F., KonwERSKI Sz., BŁoszYK J., 2014 - Influence of habitat type and natural disturbances on uropodine mite communities (Acari: Mesostigmata: Uropodina) in oak hornbeam forests in Central Europe. - Int. J. Acarol., 41: 41-52.

Pfliegler W., Bertrand M., 2011 - A new species of Labidostomma Kramer, 1879 for the fauna of Hungary (Acari: Trombidiformes: Labidostommatidae) with an overviev of the family. - Opusc. Zool. Budapest, 42(2): 177-183.

ŠTORKAN J., 1939 - Beitrage zur Kenntnis der Familie Nicolletiellidae. - Aus dem Institute für systematische Zoologie der Karl's Universität in Prag, 15: 436-453. 